\title{
Microstructural characteristics on bead on plate welding of AISI 904 L super austenitic stainless steel using Gas metal arc welding process
}

\author{
P.Sathiya $^{1 *}$, S.Aravindan ${ }^{2}$, P.M. Ajith ${ }^{1}$, B.Arivazhagan ${ }^{3}$, A. Noorul Haq ${ }^{1}$ \\ ${ }^{1}$ Department of Production Engineering, National Institute of Technology Tiruchirappalli, TamilNadu, INDIA \\ ${ }^{2}$ Department of Mechanical Engineering, Indian Institute of Technology Delhi, INDIA \\ ${ }^{3}$ Indira Gandhi Centre for Atomic Research, Kalpakkam, INDIA \\ *Corresponding Author: e-mail: psathiya@nitt.edu, Tel +91-9443494090
}

\begin{abstract}
In the present work, bead-on -plate welds were carried out on AISI $904 \mathrm{~L}$ super austenitic stainless steel sheets using Gas Metal Arc Welding (GMAW) process. In this present investigation AISI $904 \mathrm{~L}$ solid wire having $1.2 \mathrm{~mm}$ diameter was used as an electrode with direct current electrode positive polarity. Argon was employed for shielding purposes. The fusion zone is generally characterized by a few geometrical features namely bead width, bead height and depth of penetration. The shape of the fusion zone depends upon a number of parameters such as gas flow rate, voltage, travel speed and wire feed rate. Taguchi Technique is applied to plan the experiments. The bead profile parameters such as bead width, bead height and depth of penetration are measured. From the experimental results, the gray relational analysis is applied to optimize the input parameters simultaneously considering multiple output variables. In order to understand the microstructural changes occurring in the weld zone is investigated through the optical microscopy. The hardness measurements were taken across the fusion zone.
\end{abstract}

Keywords: Super austenitic stainless steel; bead geometry; Microstructural characterization; Hardness.

\section{Introduction}

Super austenitic stainless (AISI 904 L) steel is utilized extensively in the chemical, petrochemical, pulp, paper, and pollution control industries. It has the superior corrosion resistance at moderate and high temperature applications. The microstructure of super austenitic stainless steel is of fully austenitic in nature under solution quenched condition. The term super austenitic relates to austenitic stainless steel containing high amounts of molybdenum, chromium, nickel, nitrogen and possibly manganese (Liljas 1997, Di Caprio et al. 1997, Liljas and Acom 1995). Super austenitic stainless steel (AISI 904 L) is a highly alloyed austenitic low carbon stainless steel having good weldability. Due to its high molybdenum content and specially designed welding consumables with low impurity level, hot crack formation during welding can be avoided despite the fully austenitic filler metal. Super austenitic stainless steel (AISI 904 L) is primarily characterized by its excellent ductility, even at low temperatures. Ferrite free, fully austenitic stainless steel with high nitrogen content has very good impact strength and is therefore very suitable for cryogenic applications. Especially for nitrogen alloyed steel, yield and tensile strengths are generally high. This type of steel cannot be hardened by heat treatment and it is normally supplied in quench annealed condition. Super austenitic stainless steel (AISI 904L) finds applications in the production of condensers, heat exchangers and pipe work in general paper and allied industries, sea water cooling equipments, oil and refinery components and also in transport of sulfuric acid.

The utility of super austenitic stainless steel is particularly interesting because they bridge the cost wise difference between relatively cheaper austenitic stainless steel and expensive nickel base super alloys. This steel has high corrosion resistance properties at moderately high temperatures (Wallen et al., 1992). The microstructure of super austenitic stainless steel consists of a fully austenitic structure in the solution-quenched condition. However, the high amount of alloying elements, $\mathrm{Mo}, \mathrm{N}$ and $\mathrm{Cr}$ can enhance the precipitation of intermetallic phases.

The gas metal arc welding (GMAW) process is a welding method that yields coalescence of metals by heating with a welding arc between continuous filler metal (consumable) electrode and the work piece. The continuous wire electrode, which is drawn 
from a reel by an automatic wire feeder, and then fed through the contact tip inside the welding torch, is melted by the internal resistive power and heat transferred from the welding arc. Heat is concentrated by the welding arc from the end of the melting electrode to molten weld pools and by the molten metal that is being transferred to weld pools. Molten weld pools and electrode wire were protected from contaminants in the atmosphere by a shielding gas obtained from various combinations (Kim Ill-Soo et al., 2003). In gas metal arc welding the common variations of shielding gases, power supply and electrodes play significant effects in process variables by (Miami, 1981). All commercially important metals such as carbon steel, stainless steel, aluminum and copper can be welded with this process in all positions by choosing the appropriate shielding gas, electrode and welding condition Miami (1978). The composition of a shielding mixture in arc welding depends mostly on the kind of material to be welded. The selection of the shielding gas should, by all means, take into account chemical-metallurgical processes between the gases and the molten pools that occur during welding as reported by Ahmet Durgutlu (2004). Super austenitic stainless steel is Fe-based system highly alloyed with $\mathrm{Cr}, \mathrm{Ni}, \mathrm{Mo}$, and $\mathrm{N}$ to produce excellent pitting and crevice corrosion-resistant properties at high temperatures and in seawater. When exposed to elevated temperatures for long periods of time, large amounts of precipitates, including carbides, nitrides, and intermetallic phases, are formed in this steel. The most commonly observed secondary phases include $\mathrm{M}_{23} \mathrm{C}_{6}$ carbide, and intermetallic $\sigma, \chi$ and Laves phases. Other less commonly observed secondary phases include $\mathrm{M}_{6} \mathrm{C}, \pi, \mathrm{R}$, and $\mathrm{Cr}_{2} \mathrm{~N}$ (Heino et al., 1999; Heino et al., 2000; Svoboda et al., 2004; Lee et al., 2000). High amount of these phases reduces the corrosion resistance and mechanical properties of the stainless steel. The type of precipitate strongly depends on the local composition, heating time and temperature. At temperatures ranging from 700 to $1100{ }^{\circ} \mathrm{C}$, carbides are usually the first to form. At longer duration, these carbides are usually replaced by intermetallic compounds, such as $\sigma, \chi$ and Laves. Low carbon solubility has been found in $\sigma$, while a high solubility of interstitial elements in the austenite $(\gamma)$ matrix tends to favor the formation of $\chi$ and Laves phases. Increased Mo percentage favors the precipitation of intermetallic at higher temperatures. High amount of N $(0.5 \mathrm{wt}$. \%) has been found to prevent the $\chi$ phase from forming at all; instead, the formation of the Laves phase is reported (Heino et al., 1999; Heino et al., 2000; Svoboda et al., 2004). However, the Laves-phase formation is delayed with additional nitrogen (Heino et al., 2000). It is well known that nitrogen has a greater solid solubility than carbon, and it is a strong austenite stabilizer element (Simmons, 1996). Thus, the addition of nitrogen not only increases the mechanical properties of these materials but also proves useful in delaying or even preventing the formation of harmful precipitates.

The microstructural and fatigue properties of different super austenitic stainless steel like AISI 904 L, 254 SMO and AMANOX1.3964 are studied when they are welded by plasma arc and electron beam-welding. The microstructures were fully dendritic and austenitic although the interdendritic materials are richer in ferrite stabilizing elements $(\mathrm{Cr}$, Mo). The heat affected zone (HAZ) was very narrow in the electron beam welded joints due to the high cooling rate. The fatigue strength of such welded joints was found to be superior to that of the joints of ferritic - pearlitic steel (Lee et al., 2000; Heino et al., 1999; Bonollo et al., 2004). The absence of precipitates in the region near the plate surface, close to the fusion line, was justified by the cooling rate which was fast enough to prevent the precipitate formation. However, closer to the plate centers, the welding process has led to a temperature exposure at which precipitation occurred (Nastac, Stefanescu 1993). The temperature and stress fields which are computed in the laser welded region of mild steel sheets using finite element method were studied. It is found that, the temperature decay rate in the molten zone is lower than in the solid. The grain coarsening occurs in the heat affected zone and grain refinement and recrystallization takes place in the fusion zone (Yilbas et al., 2010).

Till now, only a very few literature deals with the gas metal arc welding of super austenitic stainless steel with argon as a shielding gas. Super austenitic stainless steel has hot cracking problems in high heat input welding process. In order to understand the basic microstructural changes that occurred in different heat input of GMAW process, it is essential to study the bead on plate welding of super austenitic stainless steel using GMAW process. Specific information on the gas metal arc welding of AISI 904 L super austenitic stainless steel has not yet been fully established. The present investigation is concerned with varying the input parameters and their effects on the bead profile and metallurgical properties of super austenitic stainless steel weld.

Bead geometry, which includes bead height and bead width, is an important physical property of weldments. It is said that the cooling rate of a weld can be predicted from the weld cross-sectional area and the arc-travel rate. The bead cross-sectional area together with its height and width affects the total shrinkage, which determines largely the residual stresses and thus the distortion was reported (Shumovsky, 1952). Meitzner and Stout (1966) concluded from their experimental studies with metal-arc inert gas (MIG) welding that the degree of cracking in welded joints was related more directly to the contour of the solidified bead than to the external welding parameters such as current and voltage. Several welding parameters seem to affect the bead geometry. Gurev and Stout (1963) observed in MIG welding that the bead width increased with increasing heat input into the work, i.e. with either decreasing arc-travel rate or with increasing current. It was also shown that undercutting of weld beads was associated with high arc-travel rates and also studied the effect of metal transfer characteristics on bead geometry. Under conditions of spray transfer, increased voltage produced increased bead width, but significant decrease in bead height, penetration and reinforcement area. Christensen et al. (1965) concluded that the weld cross sectional area was related to the effective heat input to the plate, the latter being obtained from arc-voltage, arc current and arc-travel rate. The effect of welding parameters at reduced atmospheric pressures on bead geometry was reported (Begeman et al., 1950) who observed that bead width and height were larger with reverse polarity than with straight polarity and that the bead width increased in direct proportion to the energy supplied.

Ronay (1960) stated that with straight polarity welding under normal atmospheric shielding, the depth of penetration was almost twice that of reverse polarity. While working with an MIG welding process, Gurev and Stout (1963) also observed that the depth 
of penetration increased with an increase in current, but decreased with a decrease in voltage and that the penetration increased as the arc-travel rate was decreased until it attained a minimum value which depends on the arc-power. The other factors which influence the penetration are heat conductivity, arc-length and arc-force. The higher the heat conductivity of a material the lower is the penetration.

Summarizing, it can be stated that the bead geometry and penetration affect the weldment characteristics and are dependent on a number of welding variables. In the present investigation an attempt was made to study some of the weldment characteristics such as bead height, bead width and depth of penetration, as affected by welding parameters like arc-voltage, travel speed, wire feed rate and gas flow rate. And also its effect of the microstructural changes in the weld zone and hardness variation across the beads on the GMA welded AISI 904 L (UNS N08904) super austenitic stainless steel.

\section{Experimental procedures}

The experiments were carried on AISI $904 \mathrm{~L}$ super austenitic stainless steel plates of size 100x40x5 mm².

Table 1. Base Material \& Filler wire Chemical Composition (Weight \%)

\begin{tabular}{|c|c|c|c|c|c|c|c|c|c|c|}
\hline Material $\rightarrow$ & Si & Mn & $\mathbf{P}$ & S & $\mathbf{C r}$ & $\mathbf{N i}$ & $\mathbf{M o}$ & $\mathbf{C}$ & $\mathbf{C u}$ & $\mathbf{F e}$ \\
\hline $\begin{array}{c}\text { Base material } \\
(\%)\end{array}$ & 0.374 & 1.522 & 0.018 & 0.004 & 19.893 & 25.557 & 4.124 & 0.018 & 1.650 & rest \\
\hline $\begin{array}{c}\text { Filler wire } \\
(\%)\end{array}$ & 0.35 & 1.7 & - & - & 20.0 & 25.5 & 4.5 & 0.01 & 1.5 & Rest \\
\hline
\end{tabular}

Table 2. L 9 orthogonal Array

\begin{tabular}{|c|c|c|c|c|}
\hline Experiments & Factor 1 & Factor 2 & Factor 3 & Factor 4 \\
\hline 1 & 1 & 1 & 1 & 1 \\
\hline 2 & 1 & 2 & 2 & 2 \\
\hline 3 & 1 & 3 & 3 & 3 \\
\hline 4 & 2 & 1 & 2 & 3 \\
\hline 5 & 2 & 2 & 3 & 1 \\
\hline 6 & 2 & 3 & 1 & 2 \\
\hline 7 & 3 & 1 & 3 & 2 \\
\hline 8 & 3 & 2 & 1 & 3 \\
\hline 9 & 1 & 3 & 2 & 1 \\
\hline
\end{tabular}

Table 3. Selection of parameters level

\begin{tabular}{|c|c|c|c|}
\hline Factors & Level 1 & Level 2 & Level 3 \\
\hline $\begin{array}{c}\text { Voltage (Volts) } \\
\text { (Factor 1) }\end{array}$ & 28 & 30 & 32 \\
\hline $\begin{array}{c}\text { Travel speed (mm/min) } \\
\text { (Factor 2) }\end{array}$ & 90 & 100 & 110 \\
\hline $\begin{array}{c}\text { Wire feed rate (m/min) } \\
\text { (Factor 3) }\end{array}$ & 1.5 & 1.75 & 2.0 \\
\hline $\begin{array}{c}\text { Gas flow rate (lpm) } \\
\text { (Factor 4) }\end{array}$ & 12 & 14 & 16 \\
\hline
\end{tabular}

The base material and filler wire chemical compositions are presented in Table 1. The filler (Avesta welding wire MIG AWS A 5.9 ER 385) wire $1.20 \mathrm{~mm}$ diameter was used in this study. Argon was used as a shielding gas and also constant current power source is used. The distance between the nozzle tips to electrode tip (electrode extension) is maintained as $15 \mathrm{~mm}$. Argon does not 
react and it does not promote oxidation so that the chemical composition of the weld metal would not be affected. For this reason, argon is widely used as the base gas in most of the shielding gases used for stainless steel welding. Argon arc is directional with a tendency to give finger shaped penetration into the work piece. Just prior to welding, sheets were cleaned with fresh stainless steel wire brush followed by acetone swabbing. The bead on plate welding was performed with a GMAW process. In this study, an L9 orthogonal array was used. Nine experiments are required to study the entire welding parameters space when the L9 orthogonal array is used. The experimental layout for the welding process parameters using the L9 orthogonal array is presented in Table 2. The level and selection of heat input parameters are presented in Table 3.

After the welding process, the specimens were sectioned and polished with suitable abrasive and diamond paste. Then, the specimens were etched with oxalic acid and electrolytic to clearly reveal the fused metal zone. The bead profiles were measured on the etched sample by optical microscopy. The Microhardness of the weldment was measured from the base metal, across the fusion line to the weld zone, in transverse direction using a Zwick Hardness testing machine under $1 \mathrm{~kg}$ load, maintained for 20 sec. Microstructural studies were carried out.

\section{Results and discussion}

The welding was performed Fronius TransSynergic 5000 series welding machine with different set of parameters. The macrograph of the welded sample is presented in Figure 1.

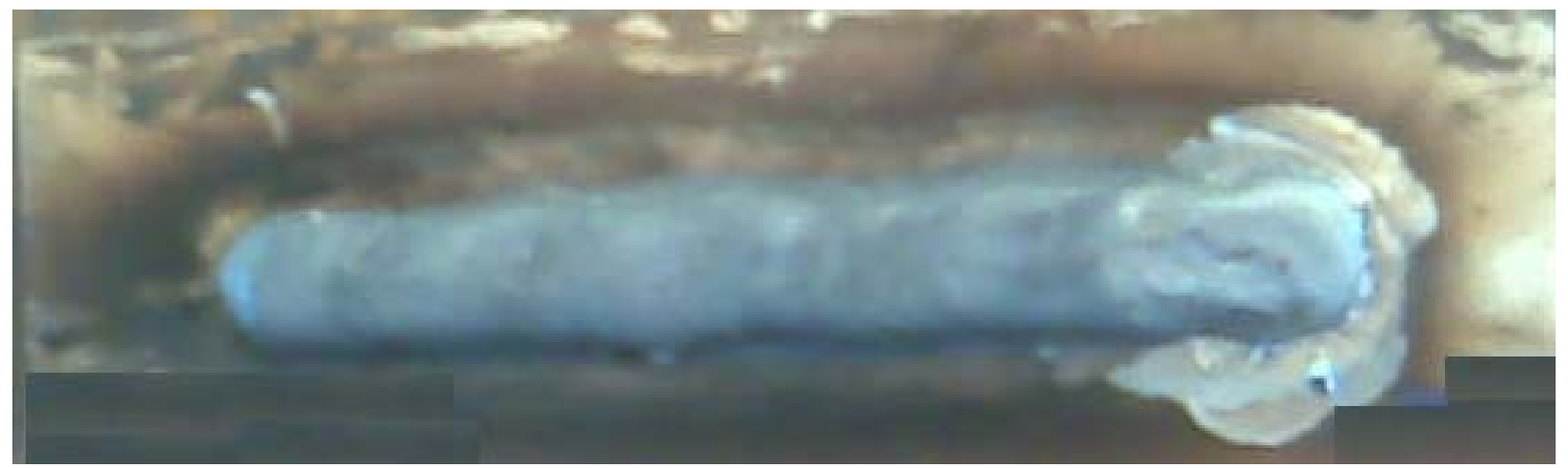

Figure 1. Macrograph of the welded sample (Experiment No.1)

From Figure 1, it is observed that the surface of the welded plate is clean and good. The weld zone, if free from cracks for all the experimental runs is considered for profile measurement. The weld bead was thoroughly examined using radiography technique to identify the soundness of weld. From both ends, $10 \mathrm{~mm}$ length weld portion were discarded. Then samples for microscopic examination are cut from the rest of the weld region. The cut samples were used to investigate the bead profile measurement, microstructural study and hardness measurements.

Table 4. Experimentally Measured values

\begin{tabular}{|c|c|c|c|c|c|c|c|}
\hline $\begin{array}{c}\text { Sl. } \\
\text { No. }\end{array}$ & $\begin{array}{c}\text { Voltage } \\
\text { (Voltage) }\end{array}$ & $\begin{array}{c}\text { Travel } \\
\text { Speed } \\
\mathbf{m m} / \mathbf{m i n}\end{array}$ & $\begin{array}{c}\text { Wire } \\
\text { feed } \\
\text { rate } \\
\mathbf{m} / \mathbf{m i n}\end{array}$ & $\begin{array}{c}\text { Gas flow } \\
\text { rate(lpm) }\end{array}$ & $\begin{array}{c}\text { Bead } \\
\text { height } \\
\mathbf{m m}\end{array}$ & $\begin{array}{c}\text { Bead } \\
\text { width } \\
\mathbf{m m}\end{array}$ & $\begin{array}{c}\text { Depth of } \\
\text { penetration } \\
\mathbf{m m}\end{array}$ \\
\hline 1 & 28 & 90 & 1.5 & 12 & 2.532 & 13.01 & 2.750 \\
\hline 2 & 30 & 100 & 1.75 & 12 & 3.699 & 10.45 & 2.439 \\
\hline 3 & 32 & 110 & 2 & 12 & 3.13 & 12.56 & 2.907 \\
\hline 4 & 28 & 100 & 2 & 14 & 3.212 & 12.01 & 2.419 \\
\hline 5 & 30 & 110 & 1.5 & 14 & 3.416 & 11.49 & 2.237 \\
\hline 6 & 32 & 90 & 1.75 & 14 & 3.435 & 10.76 & 3.211 \\
\hline 7 & 28 & 110 & 1.75 & 16 & 3.070 & 11.30 & 2.582 \\
\hline 8 & 30 & 90 & 2 & 16 & 3.659 & 11.38 & 3.354 \\
\hline 9 & 32 & 100 & 1.5 & 16 & 3.699 & 12.24 & 2.988 \\
\hline
\end{tabular}

The experimental results for the weld bead profiles are presented in Table 4. Heat input plays an important factor for determining the bead profiles. In general, due to the high amount of heat input i.e., larger amount of heat deposited on the surface leads to higher penetration. From the Table 4, the high amount of penetration was observed in the $6 \& 8$ set of parameters. When the travel speed is at a lower level, the concentration of heat input increases, which leads to the higher penetration. 


\subsection{Macrograph of the Bead Profiles:}

Using the optical microscopy, the bead profile macrographs were evaluated. The smooth bead profile micrographs are presented in Figure 2. The fusion line zone is clearly visible in all the micrographs. In Figure 2 (a-i) the depth of penetration is partially full in all the micrographs.

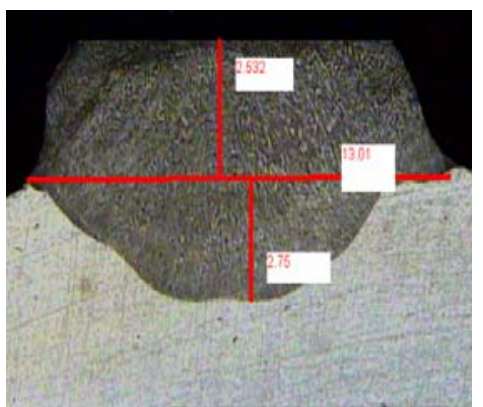

(a)

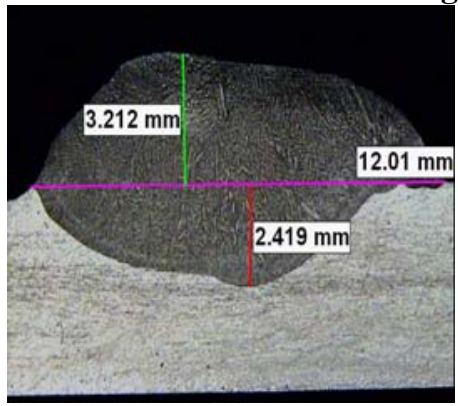

(d)

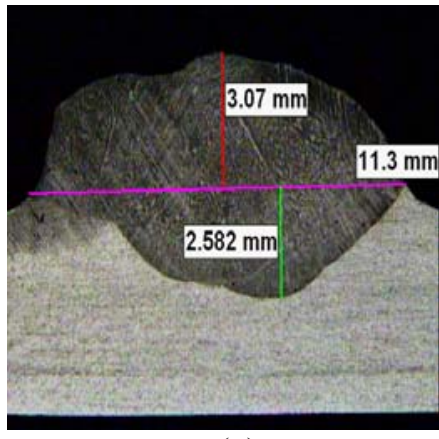

$(\mathrm{g})$

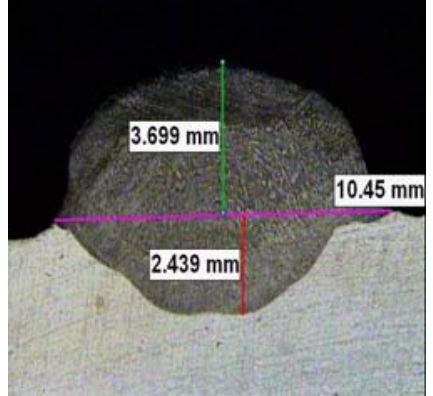

(b)

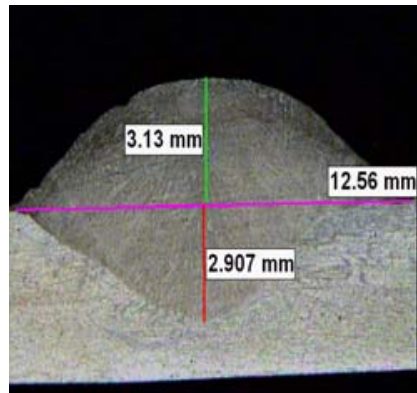

(c)

Figure 2(a-c). Macrograph of Bead Profiles

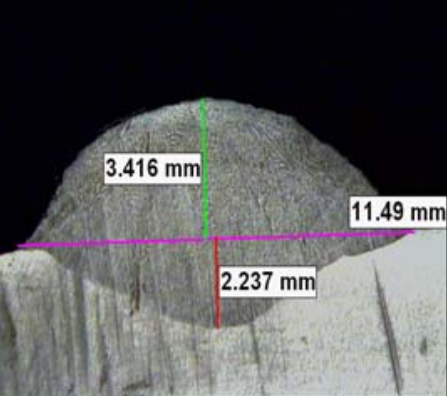

(e)

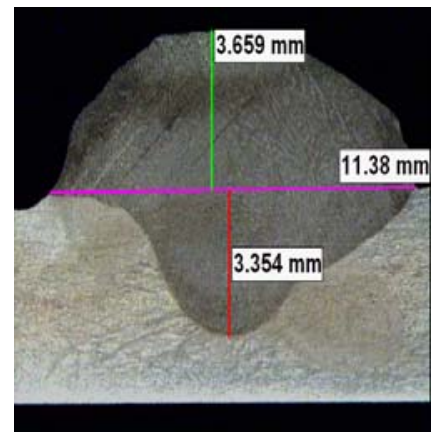

(h)

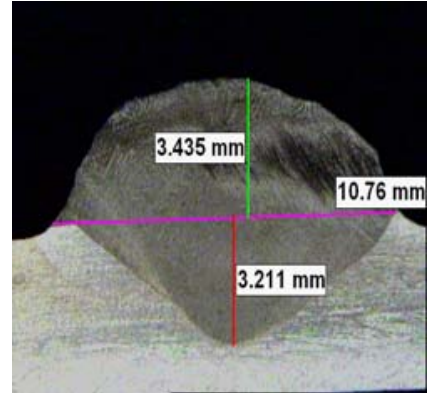

(f)

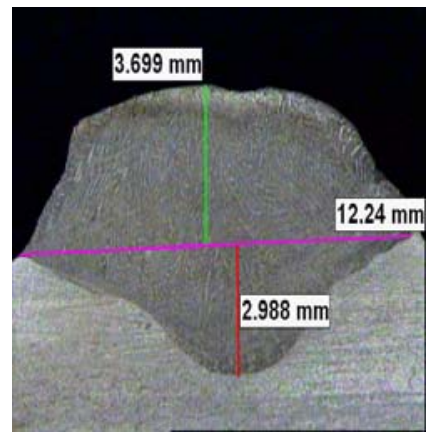

(i)

Figure 2(d-i). Macrograph of Bead Profiles

From Figure 2 (a-i), it can be observed that the surface of the welded plate is clean and good. The weld zone, if free from cracks for all the experimental runs is considered for profile measurement. Spatter and discontinuities are also not observed in the welded sample. This is confirmed that not only based on the visual inspection and also by liquid penetration test. The experimental results for the weld bead profiles are presented in Table 4.

\subsection{Effects of Chemical Composition on the Weld Metal:}

The weld metal chemical compositions and $\mathrm{Cr}_{\mathrm{eq}} / \mathrm{Ni}_{\mathrm{eq}}$ ratios are presented in Table 5. In general, the ferrite stabilizing elements such as $\mathrm{Cr}$ and Mo promote the ferrite structure and austenite stabilizing elements $\mathrm{Ni}$ and $\mathrm{N}$ promote the austenite structure. From Table 5, oxide-stabilizing elements like carbon, titanium and niobium level is low for all the weld metal. Due to this, formation of carbides can be minimized. In the $6 \& 8$ set of parameters, the level of sulphur and manganese content in the weld metal is high and because of this the depth of penetration is higher than the other weld penetration. The high amount of nickel formation in the weld metal suppresses the formation of delta ferrite. From the weld metal chemical composition, the Mn content is high to promote the formation of fully austenite structure in the weld metal. 
Table 5. Weld Metal Chemical Composition (\%)

\begin{tabular}{|c|c|c|c|c|c|c|c|c|c|c|c|c|c|c|}
\hline $\begin{array}{c}\text { Set of } \\
\text { parame } \\
\text { ters }\end{array}$ & C & Si & $\mathbf{M n}$ & $\mathbf{P}$ & $\mathrm{S}$ & $\mathrm{Cr}$ & $\mathbf{N i}$ & Mo & $\mathrm{Cu}$ & $\mathbf{N b}$ & $\mathbf{N}$ & $\mathbf{C} r_{\text {eq }}$ & $\mathbf{N i}_{\mathbf{e q}}$ & $\begin{array}{c}\mathrm{Cr}_{\mathbf{e q}} / \\
\mathrm{Ni}_{\mathbf{e q}}\end{array}$ \\
\hline 1 & 0.019 & 0.322 & 1.68 & 0.0253 & 0.0095 & 20.53 & 25.3 & 4.60 & 1.48 & 0.038 & 0.06 & 25.288 & 27.927 & 0.905 \\
\hline 2 & 0.017 & 0.330 & 1.70 & 0.022 & 0.010 & 20.55 & 25.9 & 4.6 & 1.49 & 0.0039 & 0.08 & 25.152 & 28.467 & 0.883 \\
\hline 3 & 0.018 & 0.320 & 1.71 & 0.024 & 0.012 & 20.68 & 25.3 & 4.59 & 1.48 & 0.0038 & 0.09 & 25.306 & 28.10 & 0.900 \\
\hline 4 & 0.019 & 0.316 & 1.68 & 0.023 & 0.010 & 20.61 & 25.3 & 4.61 & 1.49 & 0.004 & 0.11 & 25.255 & 28.537 & 0.884 \\
\hline 5 & 0.0189 & 0.331 & 1.64 & 0.026 & 0.005 & 20.62 & 25.1 & 4.67 & 1,52 & 0.0039 & 0.12 & 25.324 & 28.541 & 0.887 \\
\hline 6 & 0.019 & 0.327 & 1.72 & 0.024 & 0.013 & 20.69 & 25.0 & 4.87 & 1.51 & 0.0038 & 0.10 & 25.593 & 28.042 & 0.912 \\
\hline 7 & 0.019 & 0.315 & 1.65 & 0.023 & 0.012 & 20.55 & 25.41 & 4.62 & 1.5 & 0.004 & 0.11 & 25.205 & 28.65 & 0.879 \\
\hline 8 & 0.017 & 0.328 & 1.75 & 0.025 & 0.014 & 20.72 & 25.27 & 4.63 & 1.48 & 0.004 & 0.12 & 25.385 & 28.635 & 0.886 \\
\hline 9 & 0.017 & 0.322 & 1.68 & 0.024 & 0.004 & 20.53 & 25.36 & 4.62 & 1.49 & 0.004 & 0.09 & 25.184 & 28.127 & 0.895 \\
\hline
\end{tabular}

The chromium and nickel equivalents $\left(\mathrm{Cr}_{\mathrm{eq}}\right.$ and $\left.\mathrm{Ni}_{\mathrm{eq}}\right)$ with respect to the compositions of the weld zone were determined using the following empirical relation (Lu et al., 2005):

$$
\mathrm{Cr}_{\text {eq }}=\% \mathrm{Cr}+\% \mathrm{Mo}+0.7 \% \mathrm{Nb} \quad \text { and } \quad \mathrm{Ni}_{\text {eq }}=\% \mathrm{Ni}+35 \% \mathrm{C}+20 \% \mathrm{~N}+0.25 \% \mathrm{Cu}
$$

where the symbols denote the chemical compositions in weight percentage. The ratio $\mathrm{Cr}_{\mathrm{eq}} / \mathrm{Ni}_{\mathrm{eq}}$ for each set of weld metals is given in Table 5. A modified Schaffler diagram, which incorporates high cooling rates involved in welding process, was reported. This diagram indicated a relation between $\mathrm{Cr}$ and $\mathrm{Ni}$ equivalents and the phases present in the microstructure was reported (David et al. 1987). When the ratio of Creq/ $\mathrm{Ni}_{\mathrm{eq}}$ is lower than 1.35 , solidification results in austenitic formation and when it is greater than 1.35 , ferrite formation is reported. From Table 5 , it is clearly understood that the ratio of $\mathrm{Cr}_{\mathrm{eq}} / \mathrm{Ni}_{\mathrm{eq}}$ is less than 1.35 . Hence, all the weld metals are solidified in austenitic solidification mode.

Pseudo-binary diagram for the prediction of equilibrium microstructure in stainless steel is presented in Figure 3. The apparent presence of two phases has been detected and the first solidifying grains (dendrites) are certainly enriched in austenite stabilizing elements, while the ferrite stabilizing elements are rejected to the interdendritic liquid. Due to the very low $\mathrm{Cr}_{\mathrm{eq}} / \mathrm{Ni}_{\mathrm{eq}} \mathrm{value}_{\mathrm{e}}$ of this kind of steel, the interdendritic liquid is solidified as austenite phase was reported (Lippold and Savage 1979 and Raja et al. 1998).

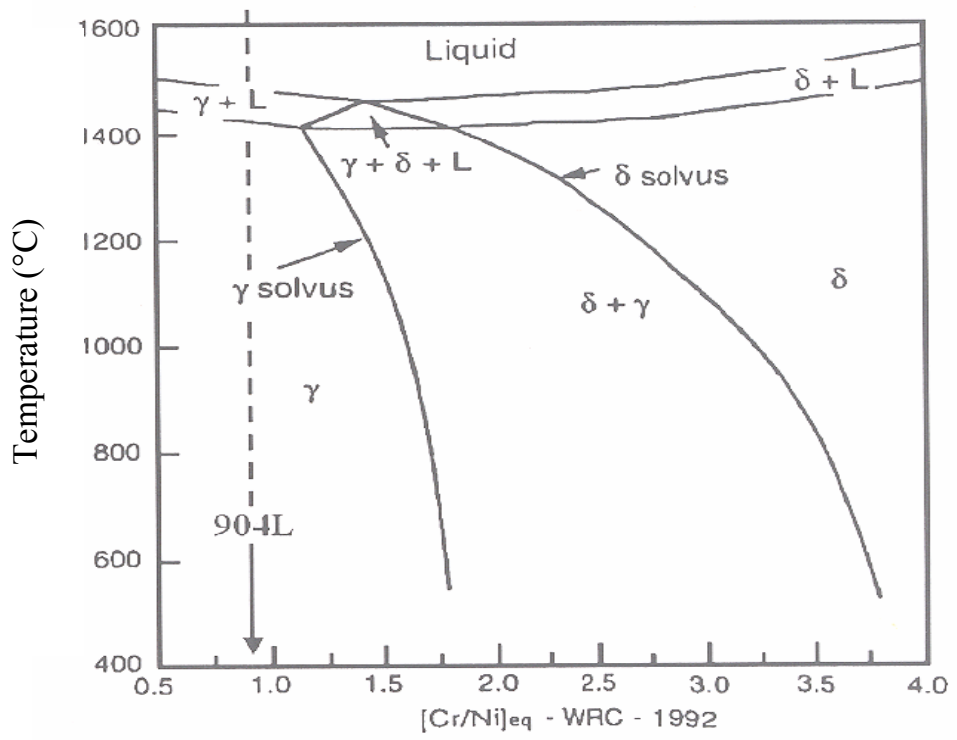

Figure 3. Pseudo-binary diagram for the prediction of equilibrium microstructure in stainless steels (Charles 1992).

\subsection{Vickers Hardness Test}

The samples were sectioned and polished with different grades of emery sheets and followed by the cloth polishing. These samples were etched for identifying the fusion line and fusion zone. The $1 \mathrm{~kg}$ load was applied up to 20 seconds. 
Table 6. Vickers Hardness values for HAZ and Weld zone

\begin{tabular}{|c|c|c|c|c|c|c|c|c|c|c|}
\hline $\begin{array}{c}\text { Set of } \\
\text { parameters }\end{array}$ & $\mathbf{1}$ & $\mathbf{2}$ & $\mathbf{3}$ & $\mathbf{4}$ & $\mathbf{5}$ & $\mathbf{6}$ & $\mathbf{7}$ & $\mathbf{8}$ & $\mathbf{9}$ & Base \\
\hline $\begin{array}{c}\text { Weld metal } \\
(\text { VHN) }\end{array}$ & 198 & 194 & 188 & 208 & 202 & 204 & 206 & 201 & 172 & \\
\cline { 1 - 7 } $\begin{array}{c}\text { HAZ } \\
(\text { VHN })\end{array}$ & 209 & 208 & 196 & 211 & 207 & 220 & 208 & 219 & 190 & 170 \\
\hline
\end{tabular}

The hardness values are determined and presented in Table 6. During solidification of the fused zone, the material generally loses its original strength induced by strain hardening effect. In the case of carbon or low alloy steel, the formation of bainite or martensitic phases in the fused zone promotes an increase in hardness. In single-phase materials, this increase in hardness in the weld metal may be induced by precipitation hardening effects, residual stresses or microstructural refinement due to the faster cooling of the weld metal. From Table 6, it is seen that the hardness of weld metal is lower than the hardness of HAZ, because of the refinement of the grain size. Due to the fast rate cooling, the grains are getting finer for improvement of the hardness values in the HAZ. The base metal hardness is lower compared to the hardness of both HAZ and weld metal. It is due to the presence of finer grains. Due to the presence of grain-refining elements, such as aluminum, niobium, vanadium, and titanium, the grains at HAZ and weld metal are refined compared to the grain size of base metal.

From the above Table, it is observed that the HAZ hardness values are higher than the weld metal. In particularly $6 \& 8$ set of hardness values are much higher than the other set of parameters. The increase in hardness value at HAZ and weld is because of fast cooling rate leading to the formation of the finer grain size.

\subsection{Microstructural Study}

As received solution annealed condition base material microstructure is presented Figure 4. Well-defined grain boundaries are shown. The 100\% austenitic phases are observed from the above Figure. In earlier investigations (Bonollo et al. 2005, Li et al. 1996 \& Raja et al., 1998) the apparent presence of two phases has been detected and attributed first to the solidifying grains (i.e. dendrites) which are certainly enriched in austenite stabilizing elements, while the ferrite stabilizers are rejected to the interdendritic liquid. However, due to the very low $\mathrm{Cr}_{\mathrm{eq}} / \mathrm{Ni}_{\mathrm{eq}}$ value, the interdendritic liquid also solidifies as austenite, due to the effect of the differences in chemical composition.

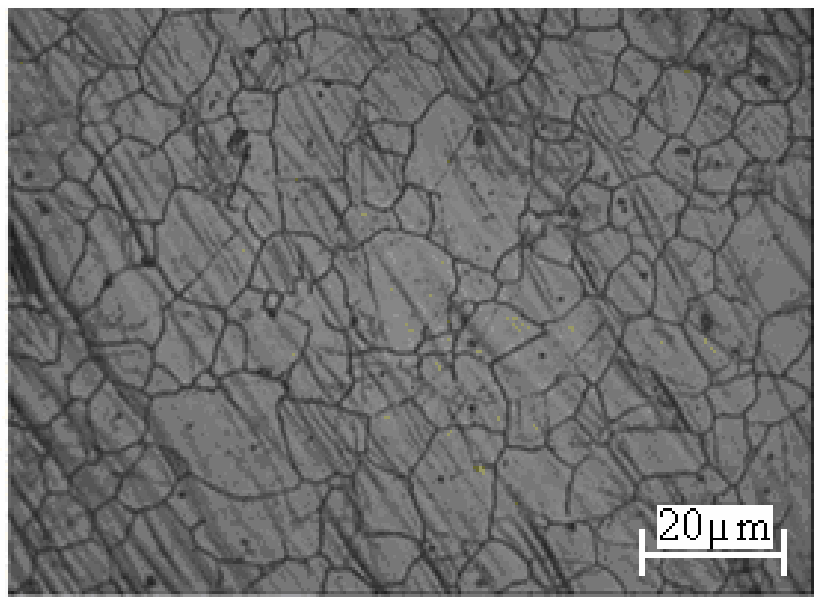

Figure 4. Base material microstructure

In the weld metal microstructure (Figure 6 (a-i)), a fully dendritic microstructure and coarse grains are observed and the darker austenite phase is primary (dendritic) and lighter one is secondary interdendritic phase. The austenite stabilizing elements such as $\mathrm{Ni}, \mathrm{N}$ and $\mathrm{C}$ first get partitioned into the primary dendrites (austenite in nature). This leads to ferrite stabilizing elements like $\mathrm{Cr}$, $\mathrm{Mo}$, and Si partitioning into the liquid phase. Along with these elements impurities also get partitioned into the liquid and become part of interdendritic (secondary phase). It is obvious from the Figure 5 (h \& i), that the secondary austenite phase becomes sharper when compared to other secondary austenite phases and occupies more area compared to primary dendrite phases. Enhancement of solute in the solidifying phase at higher cooling rate leading to the reduction in the accumulation of solute in the liquid phase and leads to sharp boundaries (Lippold and savage 1980). 


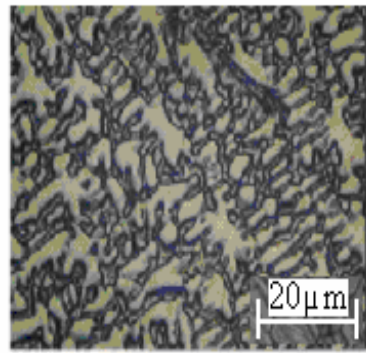

(a)

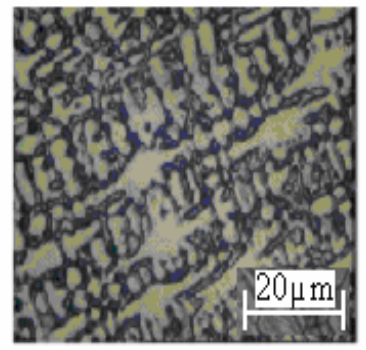

(d)

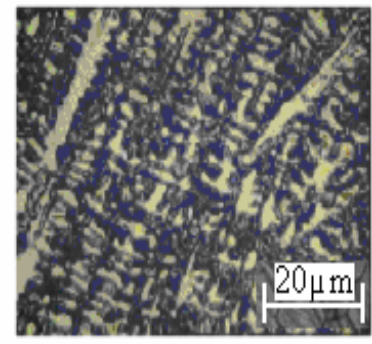

$(g)$

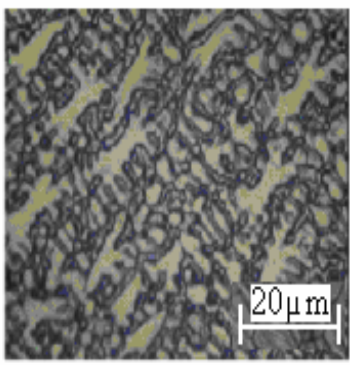

(b)

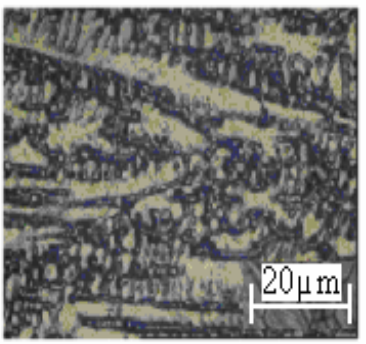

(e)

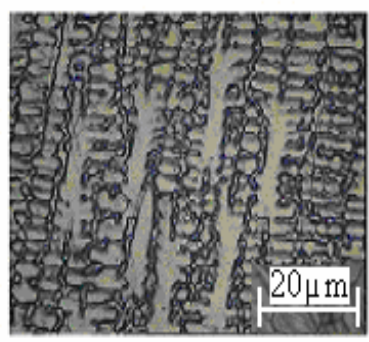

(h)

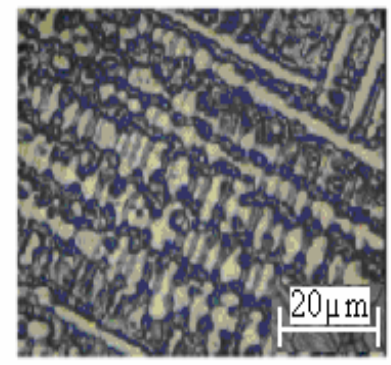

(c)

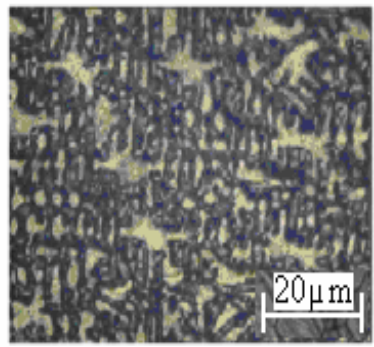

(f)

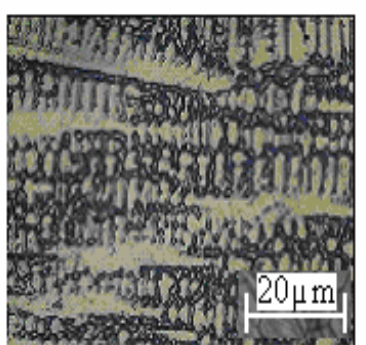

(1)

Figure 5 (a-i). Weld metal Microstructures

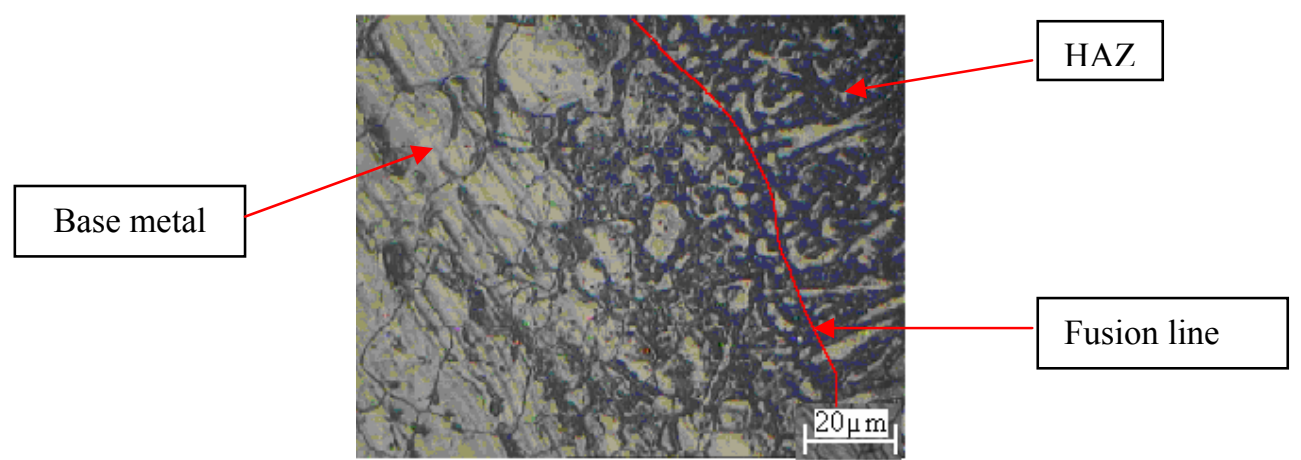

Figure 6. Base-Fusion line-HAZ microstructure

The distinguished zone microstructure is presented in Figure 6. From Figure 6, one can observe very finer fusion line grains, fine HAZ grains and coarse size base material grains. 


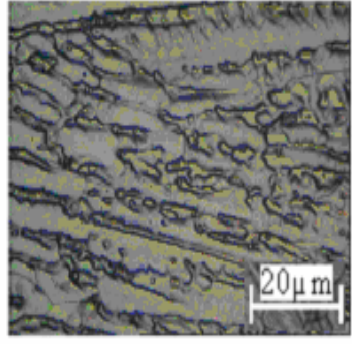

(a)

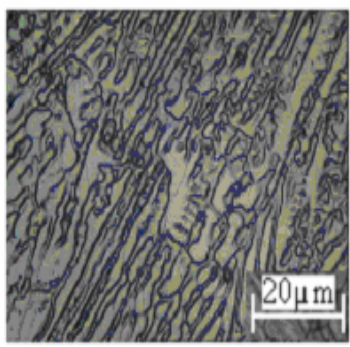

(d)

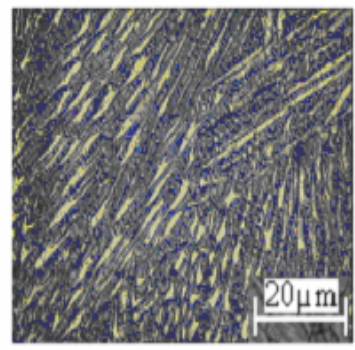

(g)

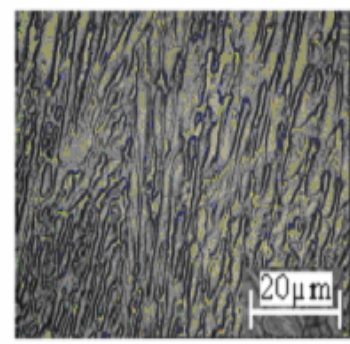

(b)

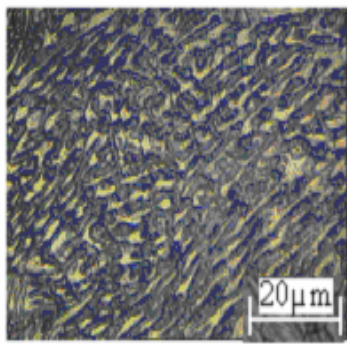

(e)

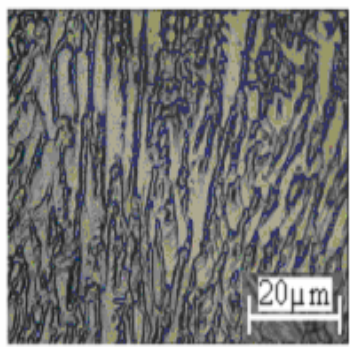

(h)

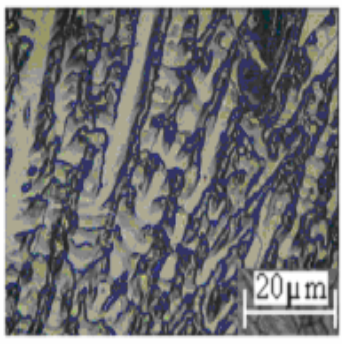

(c)

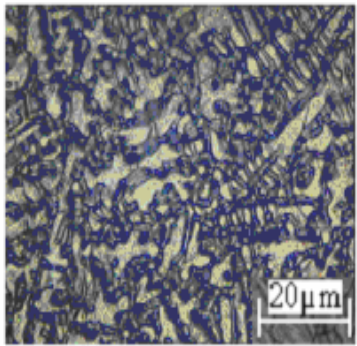

(f)

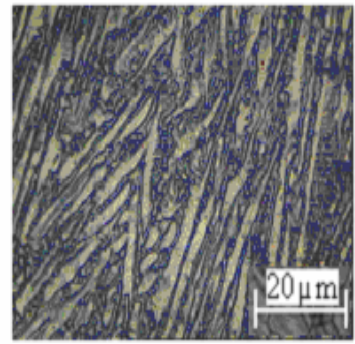

(1)

Figure 7 (a-i). Heat affected zones (HAZ) Microstructures

The HAZ microstructures appear to be characterized by fully dendritic structure as presented in Figure 7 (a-i). From Figure 7 (a i), the grains are observed in the elongated region and it presented finer grains. Compared to the weld metal microstructure the HAZ microstructures have finer elongated grains. Grains are scattered because the secondary interdendritic liquid space is more compared to the primary dendritic structure. Sharp dendritic primary phase is presented in Figure 7 (f). Comparatively the HAZ microstructure having more amounts of secondary austenite (interdendritic) phases is observed. Due to high amount of interdendritic austenitic phase and fast cooling rate the grains are getting finer.

\section{Conclusions}

The important conclusions derived from this work are:

1. When Argon is used in welding, the efficient blending of the $5 \mathrm{~mm}$ thick AISI $904 \mathrm{~L}$ super austenitic stainless steel grade was proved to be more effective.

2. The ratio of $\mathrm{Cr}_{\mathrm{eq}} / \mathrm{Ni}_{\mathrm{eq}}$ was lesser than 1.35. Hence, all the weld metals solidify in austenitic solidification mode.

3. The heat affected zone hardness values are higher than the weld metal and base metal. Due to high amount of interdendritic austenitic phase and fast cooling rate the grains are getting finer in HAZ.

4. The fully dendritic microstructure is observed in weld metal as well as HAZ. 


\section{Acknowledgement}

The authors submit their thanks to the Department of Science \& Technology (DST), New Delhi, India for the financial support for this research under Fast Track Proposal SR/FTP/ETA-11/2007.

\section{References}

Begeman. M.L, Amstead. B.H, Mashruwala. U.I, 1950, Effects of reduced atmospheric pressure on arc-welding characteristics, Welding Journal. Vol. 29, No.10, pp. 433s-440s.

Bonollo F, Tiziani A, Tovo T, Volpone LM., 2004, Super austenitic stainless steel: the microstructure and fatigue strength a welded joint. Welding International, Vol. 18, No. 1, pp. 24-30.

Bonollo. F, Tiziani. A Tovo. R, Volpone. L.M, 2005, Welding International, Vol. 18, pp. 24-30.

Christensen. N, de Davies. V.L, Gjermurdsen. K, 1965, Distribution of temperatures in arc-welding, British Welding Journal. Vol. 12, No. 2, pp. 54-75.

Charlas. J, 1992, Proceedings of the conference on application of stainless steels'92, Stockholm, Jerncontoret, pp. 1108-1121.

Colombier.L., Hochmann. J, 1968, Stainless and Heat Resisting Steels, St. Martin's Press, New York.

David .S.A., Vitek. J.M., and Hebble.T.L., 1987, Effect of rapid solidification on stainless steel weld metal. Welding Journal, vol. 66, pp. 289s-300s.

Di Caprio.G, 1997, Gli acciai inossidabili, Ulrico Hoepli Milano, Milano, Italy, pp. 62-89.

Durgutlu A., 2004, Experimental investigation of the effect of hydrogen in argon as a shielding gas on TIG welding of austenitic stainless steel, Journal of Materials \& Design, Vol. 25, No.1, pp. 19-23.

Gurev. H.S, Stout. R.D, 1963, Solidification phenomena in inert-gas metal arc welds, Welding Journal, Vol. 42, No. 7, pp. 298s$310 \mathrm{~s}$.

Heino S, 2000, Role of Mo and W During Sensitization of Super austenitic Stainless Steel-Crystallography and Composition of Precipitates. Metallurgical \& Materials Transaction A, Vol. 31A, pp. 1893-2904.

Heino S, Knutson-Wedel M Karlsson B, 1999, Precipitation behavior in heat affected zone of welded super austenitic stainless steel, Materials science and Technology, Vol. 15, No. 1, pp. 101-108.

Heino S, Knutson-Wedel M, Karlsson B,1999, Precipitation in a High Nitrogen Super austenitic Stainless Steel, Material Science Forum, Vol. 318-320, pp. 143-148.

Kim Ill-Soo., Son Joon-Sik., Yarlagadda Prasad KDV, 2003, A study on the quality improvement of robotic GMA welding process, Robot CIM-International Journal of Manufacturing, Vol. 19, No. 6, pp. 567-572.

Lee TH, Kim SJ, Jung YC, 2000, Crystallographic Details of Precipitates in Fe-22Cr-21Ni-6Mo-(N) Super austenitic Stainless Steels aged at $900{ }^{\circ} \mathrm{C}$, Metallurgical \& Materials Transaction A, Vol. 31A, pp. 1713-1723.

Liljas. M, 1997, Scandinavian Journal of Metallurgical, pp. 32-58.

Liljas.M, Acom, 1995, Avesta Sheffileld AB (publ) (ISSN 1101-0681), http://www.avestapolarit.com/upload/documents/technical/acom/acom952.pdf., 2, pp. 1-7.

Li. R, Ferreira.M.G.S, Anjos.,M.A, Vilar.R, 1996, Journal of Surface Coating Technology, Vol. 88, pp. 90- 95.

Lippold. J.C. and Savage, W.F., 1980, Welding Journal, 48s- 54s.

Lu .B.T., Chen. Z.K., Luo. J.L, Patchett B.M., Xu. Z.H, 2005, Pitting and stress corrosion cracking behavior in welded austenitic stainless steel, Electro-chemical Acta, Vol. 50, No. 66, pp. 1391-1403.

Meitzner. C.F, Stout. R.D., 1996, Micro-cracking and delayed cracking in welded quenched and tempered steels, Welding Journal. Vol. 45, No. 9, pp. 381s-386s.

Miami. F.L, 1981, welding handbook fundamentals of welding, Vol. 1, 7th Ed, American Welding Society, pp. 7-9.

Miami. F. L, 1978, Welding handbook welding processes-arc and gas welding and cutting, brazing and soldering, Vol. 2, 7th Ed. American Welding Society, pp. 114-6.

Nastac L, Stefanescu LM (1993). An analytical model for solute redistribution during solidification of planar, columnar, or equiaxed morphology, Metallurgical Transaction A, Vol. 24 A, pp. 2107-2118.

Raja. V.S., Varshney. R, Raman. R and Kulkarni. S.D., 1998, Influence of nitrogen on the pitting corrosion behavior of 904L weld clad, Corrosion Science, Vol. 40, pp. 1609-1625.

Raja.V.S, Varshney.S.K, Raman. R, Kulkarni. S.D, 1998, Corrossion Science, Vol. 40, pp. 1609- 1625.

Ronay. B, 1960, The importance of polarity in arc welding, Welding Engineer, Vol. 45, No. 3, pp. 32-33.

Shumovsky, 1952, Controlling welding shrinkage and distortion, The Canadian Welder, pp. 179-192.

Simmons JW, 1996, Overview: High nitrogen alloying of stainless steels, Materials science and Engineering A, Vol. 207, pp. 159169.

Svoboda M, Kroupa A, Soousek J, Vrestal J, Miodownik P, 2004, Phase Changes in Super austenitic Steels after Long-Term Annealing, Zeitschrift Fur Metallkunde, Vol. 95, pp. 1025-1030.

Yilbas BS, Arif AFM, Abdul Aleem BJ (2010). Laser welding of low carbon steel and thermal stress analysis, Optics and Laser Technology, vol. 42, No. 5, pp. 760-768. 
Wallen.B, Liljas.M, Stenvall.P, 1992, Proceedings of the Conference on Applications of Stainless Steel, Stockolm, pp. 9-11.

\section{Biographical notes}

Dr. P.Sathiya is currently working as Associate Professor in Department of Production Engineering, National Institute of Technology, Tiruchirappalli, Tamilnadu, India. He did his Ph.D. (Welding) from National Institute of Technology, Tiruchirappalli, Tamilnadu, India. He has more than 15 years of experience in teaching and research. He has published thirty research papers in national and international journals and forty research papers in conferences. His research interests are in broad areas of production engineering with specific interest in metal joining process, welding parameter optimization, fatigue and fracture analysis.

Dr. S. Aravindan is currently working as Assistant Professor in Department of Mechanical Engineering, Indian Institute of Technology Delhi, New Delhi, India. $\mathrm{He}$ did his Ph.D., from Indian Institute of Technology Madras, Chennai and Post Doctoral Fellowship in Tokyo University, Tokyo, Japan. He has published more than fifty research papers in national and international conferences and in journals. His research interests are in broad areas of Manufacturing with specific interest in composite joining, welding, machining and metal cutting.

Dr. A.Noorul Haq is currently working as Professor in Department of production Engineering, National Institute of Technology, Tiruchirappalli, Tamilnadu, India. He did his Ph.D. from Indian Institute of Technology Delhi, New Delhi, India. He has published more than 100 research papers in national and international journals and in conferences. His research interests are in broad areas of production engineering with specific interest parameter optimization, supply chain management and scheduling.

Received July 2010

Accepted October 2010

Final acceptance in revised form November 2010 